cipally with studies of radio stars. The main instrument will be an interferometer consisting of two steerable parabolic reflectors, each $90 \mathrm{ft}$. in diameter and having a mesh covering suitable for use down to $3 \mathrm{~cm}$. The reflectors are each mounted on bogies on 35-ft. gauge railway tracks running north-south and east-west, so that when the pair is used as an interferometer the spacing and orientation can be varied.

\section{The Institution of Electrical Engineers :}

Mr. C. W. Speirs

Mr. Charles W. Speirs has been elected to honorary membership of the Institution in recog. nition of his contributions to the advancement of electrical science and engineering, and of his outstanding support for the work of the Institution, particularly of its Incorporated Benevolent Fund. Mr. Speirs studied at the University of Durham and in 1891 entered the works of Messrs. C. A. Parsons and Co. at Heaton as an engineering apprentice. In 1898 he joined the Morgan Crucible Co., Ltd., as engineer and technical adviser, remaining with that organization until his retirement in 1933 . In $1944 \mathrm{Mr}$. Speirs made a substantial gift of land from his estate at Malden, accompanied by a notable endowment, to the Incorporated Benevolent Fund. These gifts, supplemented by the contributions of members to the 'Homes Fund', brought into being the residential estate for beneficiaries of the Fund known as the Chesters Estate.

\section{Signor Luigi Emanueli : Faraday Medallist}

Signor Luigi Emanueli (who, we regret to announce, died on February 17) has been awarded the thirty-seventh Faraday Medal of the Institution of Electrical Engineers for his outstanding contribution of inventions and new applications in the field of electrical cables, and particularly for the invention of the oil-filled cable. Signor Emanueli, who was born in Milan in 1883, graduated in electrical engineering from the Milan Polytechnic in 1906. He is vice-president of the Pirelli Company of Milan, where he started his professional life in 1907. He was elected a member of the Institution of Electrical Engineers in 1922. Signor Emanueli has been connected with numerous scientific inventions and applications in the electrical cable and the rubber industries including the oil-filled cable, universally known as the Emanueli cable, which represents a turning point in technical progress in this field.

\section{Increased Grants for Universities in Britain}

IN a written answer in the House of Commons on February 9, the Chancellor of the Exchequer, Mr. D. H. Amory, said that the University Grants Com. mittee has recommended that in consequence of unexpected increases in student members and also increases in costs, the recurrent grants to universities in Britain for the last three years of the quinquennium should be increased. Existing grants were fixed on the expectation that by 1961-62 the number of full-time students would rise to about 102,000. In the current academic year this estimate would be exceeded by at least 6,500 and by the end of the quinquennium the increase was likely to be even greater. Mr. Amory said he is satisfied that some further assistance should be given to the universities and stated that he proposed to ask Parliament to provide for an increase of $£ 2,550,000$ in the recurrent grants for $1959-60, £ 2,660,000$ for
$1960-61$ and $£ 2,720,000$ for $1961-62$, exclusive of the provision required to meet the improved salary scales announced on March 12, 1957.

\section{Research on Fuel and Power in Britain}

The Parliamentary Secretary to the Ministry of Power, Sir Ian Horobin, replied in the House of Commons on Monday, February 9, to a series of questions about fuel and power research. $\mathrm{He}$ said that the Scientific Advisory Council of the Ministry of Power is concerned with the co-ordination and development of research in the utilization of the fuel resources of Britain. The Council works under an independent chairman and includes representatives of the fuel and power industries, the Department of Scientific and Industrial Research, industry generally and the universities. Experimental work with liquid methane is being paid for by the British gas industry and the American interests concerned, and the total cost to the gas industry is estimated at fl.5 million. The National Coal Board has decided to terminate experimental work on underground gasification at Newman Spinney on the ground that present results do not justify further expenditure. Research on the production of gas from oil is being concentrated upon hydrogenation of oil, and a commercial plant to work initially on oil and later on coal has been commissioned by the Gas Council. The gas industry estimates that its consumption of tail gas and other refinery surpluses may increase, in terms of coal equivalent, from the present 500,000 tons to 2 million tons in $\mathbf{1 9 6 5}$.

\section{The Tropical Products Institute}

The Tropical Products Institute is to become one of the research stations of the Department of Scientific and Industrial Research, following the decision to transfer the responsibility for the Institute from the Secretary of State for the Colonies to the Lord President of the Council, so that Commonwealth countries which have recently achieved independence, and thus no longer come within the scope of the Colonial Office, may still avail themselves of the services of the Institute. Support will continue to be provided by the Colonial Office, from the Colonial Development and Welfare Funds, for work of primary interest to the Colonies. The main objective of the Tropical Products Institute is to ensure the economic viability of the under-developed territories of the Commonwealth within the tropics, by improving the technology of industries that already exist and intro. ducing new industries as a result of research into new uses for tropical plant and animal products (including waste products of existing industries). Particular attention will be directed to the needs for diversification in those territories which have a one-crop economy.

\section{New European Nuclear Energy Project}

THE third international project in the programme of the European Nuclear Energy Agency for the development of nuclear power for peaceful purposes on a European basis has been approved by the Agency's Steering Committee. Six Europenn countries, together with Euratom, will combine in a joint investigation of the use of high-temperature gascooled reactors for nuclear power stations and other applications. The new project, known as Dragon, will be based mainly on the construction of an experimental power-producing reactor, developing 